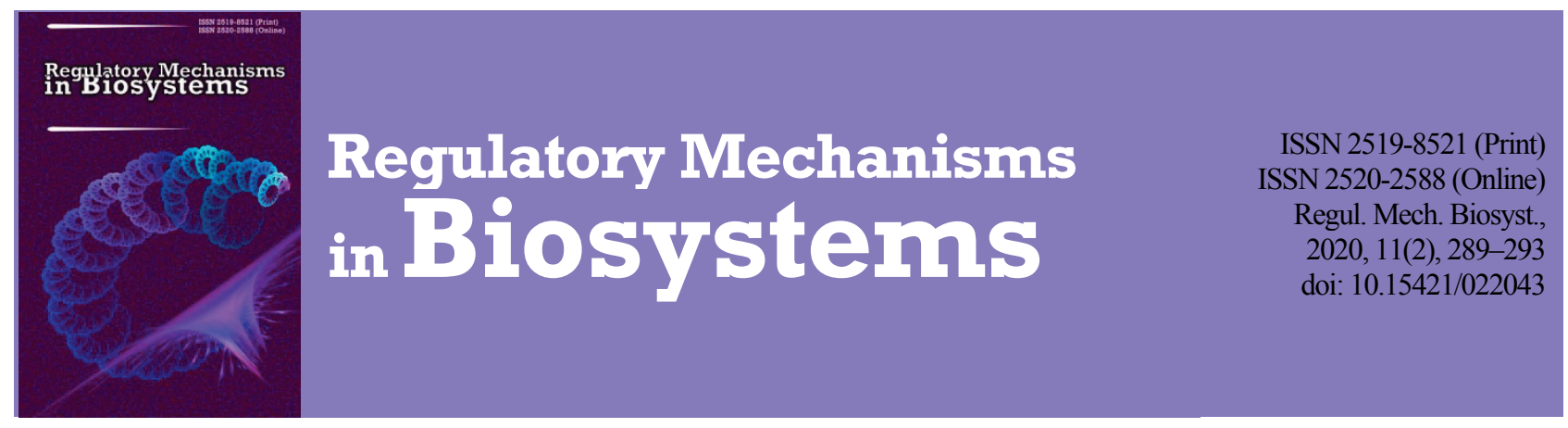

\title{
The impact of humic acid additives on mineral metabolism of rabbits in the postnatal period of ontogenesis
}

\author{
M. A. Rybalka, L. M. Stepchenko, O. O. Shuleshko, L. V. Zhorina \\ Dnipro State Agrarian and Economic University, Dnipro, Ukraine
}

Article info

Received 10.04.2020

Received in revised form 15.05.2020

Accepted 17.05.2020

Dnipro State Agrarian and Economic University Serhii Efremovst., 25,

Dnipro, 49600, Ukraine.

Tel.: +38-050-642-80-81.

E-mail:

stepchenko2@gmail.com

\begin{abstract}
Rybalka, M. A., Stepchenko, L. M., Shuleshko, O. O., \& Zhorina, L. V. (2020). The impact of humic acid additives on mineral metabolism of rabbits in the postnatal period of ontogenesis. Regulatory Mechanisms in Biosystems, 11(2), $289-293$. doi:10.15421/022043
\end{abstract}

Humic acids are characterized by chelating properties due to which they are able to influence the mineral metabolism in animals. Rabbits have species-specific characteristics of mineral metabolism, which distinguishes them from most species of mammals. For the experiment, 16 rabbits of 45-day-old of Hyplus breed were divided into the experimental and control group of 8 rabbits in each. The animals were 15 days in the preparatory period. The rabbits of the experimental group received humic acid additive individually with water in the amount of $5 \mathrm{mg} / \mathrm{kg}$, the rabbits of the control group received pure water in the same amount. The ability of humic acid additive to increase the content of calcium, ionized calcium, iron, to correct the content of copper and zinc, and also to increase the activity of alkaline phosphatase in the blood serum of rabbits of the experimental group has been proved. We observed the early effect of the humic acid additive on increasing the content of iron and calcium ionized and a later effect on the activity of alkaline phosphatase and an increase in the content of copper in the blood serum. The influence of humic acid additive on the distribution of calcium, phosphorus, manganese, copper and zinc in bone tissue is determined. According to a histological study, there was a significant increase in the number of layers of osteons and osteoblasts in the bone tissue of the femur, an increase in the number of osteons and osteoblasts in the bone tissue of the sternum and an increase in the number of columns of chondrocytes and an increase in the number of chondrocytes in the column in the cartilaginous tissue of the sternum. The results of a histological study of bone tissue, together with an increase in structural macroelements in it and redistribution of osteotropic trace elements in the blood and bone tissue suggest the possibility of using a humic acid additive to intensify the growth and mineralization of bone tissue, which can improve the state of bone tissue of rabbits in the postnatal period ontogenesis.

Keywords: humic acid; humic substances; macroelements; microelements; mineral metabolism; rabbit; bone tissue.

\section{Introduction}

The quality of production of rabbit meat is influenced by metabolic processes, which depend on the feeding, animal welfare and other technological processes used in the meat industry (Jerney et al., 2017). Special attention should be drawn to metabolism of mineral substances which take part in upregulation of enzyme systems, being a part of enzymes, vitamins and hormones, and providing continuous osmotic pressure in liquids of the organism

One of the tissues most sensitive to disturbances in mineral metabolism is bone tissue due to the plastic function of macronutrients (Gromova et al., 2014). Unlike with the majority of mammalian species, rabbits' intestinal absorption of calcium takes place mostly by passive diffusion in conditions when there is a sufficient amount of calcium in their diet (Quesenberry \& Carpenter, 2011). Active absorption of calcium caused by $\mathrm{D}_{3}$ vitamin influence take place only when the amount of calcium has been decreased in the diet (Varga et al., 2014). Unlike calcium, phosphorus is regulated indirectly in the rabbit organism through the active form of $\mathrm{D}_{3}$ vitamin and is absorbed in the small intestine with the help of active transport (De Blas \& Wiseman, 2010). Also, the special attention should be drawn to the ability of rabbits ingest phosphorus better than results from the caecum phytases microbiota production, which increases the amount of phosphorus available for digestion (Marounek et al., 2009).

Beside plastic function of macronutrients, micronutrients play the important role important in the bone tissue development. In particular, zinc which is a constituent of alkaline phosphatase, which takes part in bone tissue development. Besides, copper, and zinc influence collagen fusion which is an organic component of bone matrix. The other component of organic matrix of bone tissue is protein-glycan, the synthesis of which is greatly influenced by manganese-dependent enzymes (Gromova et al., 2014). Particular attention is drawn to the antagonistic relationship with the absorption of trace elements. There is uncertainty about the role of the DMT1 transporter in the absorption of zinc and copper, because each of these trace elements have more specific transporters. Thus, in the absorption of zinc, the main role is played by the ZIP transporter family, and in the absorption of copper by CTR1 and ATP7A transporter (Hullár et al., 2018). Also controversial is the question of the affinity of the DMT1 transporter for copper absorption (Garrick et al., 2006). The importance of the exchange of mineral substances, their significant effect on the metabolism and development of bone tissue, as well as the ambiguity of views on the mechanism of their assimilation, determine the importance of finding ways to intensify mineral metabolism.

There are several ways to solve the problem. An increase in the number of macro- and micronutrients in the diet due to the introduction of products containing large quantities of macro- and micronutrients (Mattioli et al., 2019). Another way is to add to the diet of rabbits more accessible to assimilation forms of macro- and microelements, which include chelated microelements (Beshkenadze et al., 2016). A fairly effective method is to add biologically active substances to the rabbit's diet that have chelating properties that can interact with macro- and microelements in the intestines, improving their absorption. Of particular interest among this group of substances are humic acid additive, as substances with pronounced che- 
lating properties (Islam et al., 2005). Humic acid additives are distinguished by their immunostimulating, anti-inflammatory, adaptogenic properties and the ability to correct metabolism (Stepchenko et al., 2008; Myhaylenko et al., 2016; Rybalka et al., 2016; Stepchenko et al., 2019). They can also affect the absorption and distribution of macro- and micronutrients, which was demonstrated by studies on many animal species (Skorik, 2008; Yefimov \& Rakytianskyi, 2012; Stepchenko \& Skorik, 2012; Trckova et al., 2018). Questions on the possibility of the influence of a humic acid additive on the distribution of macro- and microelements in the blood and bone tissue of rabbits are open. Therefore, the purpose of this article was to determine the effect humic acid additive on the distribution of macro- and microelements in the blood and bone tissue.

\section{Materials and methods}

Manipulations with animals were carried out in accordance with the rules of the "European Convention for the Protection of Vertebrate Animals Used for Experimental and Other Scientific Purposes" (Strasbourg, 1985). The methodology was analyzed and approved by the local ethical committee DDAEU.

The experiment was carried out on 16 Hyplus rabbits aged 45-days. The animals were kept under vivarium conditions of Dnipro State Agrarian and Economic University in cages with 4 individuals in each.

The rabbits were divided into control and experimental groups with 8 rabbits in each, according to the analogue rule (based on sex and body weight). The rabbits were fed with a special full-feed compound feed used in LLC "Agro-Soyuz-Kyiv" for growing Hyplus rabbits.

Before the experiment, the rabbits of the control and experimental groups were in the adaptation period of 15 days. At the beginning of the experiment, the age of the rabbits was 60 days. The rabbits of the experiment group were given Humilide with water individually at a dose of $5 \mathrm{mg} / \mathrm{kg}$. Rabbits of the control group received pure water in appropriate quantities. The experimental and control group of animals were in the same conditions of feeding and keeping.

Blood was withdrawn from rabbits of the control and experimental group in the morning on an empty stomach from v. Saphena lateralis on the first, 14th, 21st, 35th day of the study. The content of calcium, phos- phorus, and iron in the blood serum was measured by an absorption photometry using automatic analyzer a Cobas Integra 400 plus (Roche Diagnostics, Switzerland). Ionized calcium level were determined by ion selective potentiometry method using an AVL 9180 (Dialogue Diagnostics, Switzerland). Before further testing, bone samples were dried to a completely dry substance. The level of copper, zinc, manganese in the blood serum and the content of iron, copper, zinc, manganese in the diaphyseal part of the femur and in sternum segments were determined using an atomic absorption spectrophotometer S 115 M1 (Selmi, Ukraine). The study of macronutrients was carried out according to generally accepted methods. The concentration of all elements in the selected material is given per $1 \mathrm{~kg}$ of dry matter. For the histological examination, the diaphyseal part of the femur and several segments of the sternum were selected with preservation of their synchondrosis, the selected material was fixed in a $10 \%$ solution of neutral formalin, further research was carried out according to the generally accepted method of histological examination of bone tissue. Histological section were stained with hematoxylin and eosin.

To determine the joint and independent effect of the biologically active feed additive and age on the content of macro- and microelements in the blood serum of rabbits, we used a repeated measures two-way analysis of variance (ANOVA) with Bonferroni post hoc tests. To compare the data obtained from the rabbits of the control and experimental groups in the study of the content of macro-micronutrients in the bone tissue and in histological studies we used one-way analysis of variance (ANOVA) with Bonferroni post hoc tests. Differences were considered significant at $\mathrm{P}<$ 0.05 . The data in the tables are presented as $\mathrm{x} \pm \mathrm{SD}(\mathrm{x} \pm$ standard deviation $)$.

\section{Results}

Biologically active feed additive of humic nature and age of animals independently influence calcium content (biologically active feed additive of humin nature, $\mathrm{P}<0.05$ age, $\mathrm{P}<0.01$ ) in the blood of rabbits. There were no significant changes between the rabbits of the control and experimental groups during the experiment (Table 1). We noted an increase in calcium content of $27.8 \%(\mathrm{P}<0.05)$ in the experimental group on the 35 th day compared with rabbits of the experimental group on the first day of the experiment.

\section{Table 1}

The content of macro- and microelements, the activity of alkaline phosphatase in blood serum of rabbits under the impact of humic acid additives $(\mathrm{x} \pm \mathrm{SD}, \mathrm{n}=8$, duration of the experiment -35 days)

\begin{tabular}{|c|c|c|c|c|c|c|c|c|}
\hline \multirow{2}{*}{ Indices } & \multicolumn{2}{|c|}{ First day of the experiment } & \multicolumn{2}{|c|}{ 14th day of the experiment } & \multicolumn{2}{|c|}{ 21st day of the experiment } & \multicolumn{2}{|c|}{ 35st day of the experiment } \\
\hline & control group & experimental group & control group & experimental group & control group & experimental group & control group & experimental group \\
\hline $\mathrm{Ca}, \mathrm{mmol} / \mathrm{L}$ & $2.91 \pm 0.28^{b}$ & $2.95 \pm 0.34^{\mathrm{b}}$ & $3.00 \pm 0.33^{\mathrm{ab}}$ & $3.54 \pm 0.94^{\mathrm{ab}}$ & $3.30 \pm 0.18^{\mathrm{ab}}$ & $3.40 \pm 0.70^{\mathrm{ab}}$ & $3.36 \pm 0.24^{\mathrm{ab}}$ & $3.72 \pm 0.14^{\mathrm{a}}$ \\
\hline $\mathrm{Ca}^{2+}, \mathrm{mmol} / \mathrm{L}$ & $1.41 \pm 0.14^{\mathrm{b}}$ & $1.49 \pm 0.13^{\mathrm{b}}$ & $1.57 \pm 0.05^{\mathrm{b}}$ & $1.84 \pm 0.10^{\mathrm{a}}$ & $1.52 \pm 0.08^{\mathrm{b}}$ & $1.82 \pm 0.15^{\mathrm{a}}$ & $1.39 \pm 0.15^{\mathrm{b}}$ & $1.53 \pm 0.07^{b}$ \\
\hline $\mathrm{P}, \mathrm{mmol} / \mathrm{L}$ & $3.25 \pm 0.44^{\mathrm{ab}}$ & $2.91 \pm 0.39^{b c}$ & $2.92 \pm 0.10^{b c}$ & $3.12 \pm 0.49^{\mathrm{abc}}$ & $2.52 \pm 0.20^{c}$ & $2.77 \pm 0.47^{\mathrm{bc}}$ & $3.31 \pm 0.30^{\mathrm{ab}}$ & $3.75 \pm 0.30^{\mathrm{a}}$ \\
\hline $\mathrm{Mg}, \mathrm{mmol} / \mathrm{L}$ & $1.33 \pm 0.12^{\mathrm{b}}$ & $1.25 \pm 0.16^{\mathrm{b}}$ & $1.37 \pm 0.16^{b}$ & $1.30 \pm 0.18^{\mathrm{b}}$ & $1.20 \pm 0.05^{\mathrm{b}}$ & $1.24 \pm 0.17^{b}$ & $1.61 \pm 0.06^{\mathrm{a}}$ & $1.68 \pm 0.08^{\mathrm{a}}$ \\
\hline $\mathrm{Fe}, \mu \mathrm{mol} / \mathrm{L}$ & $22.7 \pm 2.2^{c}$ & $23.4 \pm 2.1^{\mathrm{c}}$ & $23.2 \pm 2.0^{\mathrm{c}}$ & $28.9 \pm 1.0^{\mathrm{a}}$ & $25.2 \pm 1.5^{\mathrm{bc}}$ & $29.1 \pm 1.2^{\mathrm{a}}$ & $23.4 \pm 2.2^{c}$ & $28.2 \pm 1.8^{\mathrm{ab}}$ \\
\hline $\mathrm{Zn}, \mu \mathrm{mol} / \mathrm{L}$ & $54.4 \pm 6.8^{\mathrm{a}}$ & $56.6 \pm 4.2^{\mathrm{a}}$ & $55.9 \pm 16.2^{\mathrm{a}}$ & $53.3 \pm 4.5^{\mathrm{a}}$ & $56.9 \pm 4.3^{\mathrm{a}}$ & $51.9 \pm 1.2^{\mathrm{a}}$ & $59.8 \pm 6.8^{\mathrm{a}}$ & $50.2 \pm 2.3^{\mathrm{a}}$ \\
\hline $\mathrm{Cu}, \mu \mathrm{mol} / \mathrm{L}$ & $17.2 \pm 5.4^{\mathrm{c}}$ & $19.5 \pm 2.6^{\mathrm{c}}$ & $19.9 \pm 2.7^{\mathrm{bc}}$ & $17.4 \pm 3.4^{\mathrm{c}}$ & $20.6 \pm 2.8^{\mathrm{bc}}$ & $24.8 \pm 1.1^{\mathrm{ab}}$ & $21.0 \pm 2.8^{\mathrm{abc}}$ & $25.7 \pm 1.7^{\mathrm{a}}$ \\
\hline $\mathrm{ALP}, \mathrm{u} / \mathrm{L}$ & $151 \pm 12^{\mathrm{b}}$ & $140 \pm 8^{b}$ & $143 \pm 11^{\mathrm{b}}$ & $146 \pm 16^{\mathrm{b}}$ & $149 \pm 17^{b}$ & $147 \pm 18^{b}$ & $142 \pm 13^{b}$ & $179 \pm 9^{\mathrm{a}}$ \\
\hline
\end{tabular}

Note: different letters indicate the values significantly differing one from another within a line on the results of comparison using repeated measures two-way analysis of variance (ANOVA) with Bonferroni post hoc tests.

The concentration of ionized calcium (humic acid additive, $\mathrm{P}<0.001$; age, $\mathrm{P}<0.001$ ) in the blood of rabbits was reliably influenced by the age of animals and humic acid additive, but the joint influence of the two factors was not revealed. We observed a significant increase in the content of ionized calcium in the experimental group compared with the control by $17.2 \%(\mathrm{P}<0.05)$ on the 14 th day of the study and by $19.7 \%(\mathrm{P}<0.05)$ on the 21st day. We noted age-related differences in the concentration of calcium in the blood of rabbits. We noted an increase in ionized calcium in the experimental group by the 14th and 21st days of the experiment compared with the data of the experimental group at the beginning on the first and 35 th days of the experiment.

The main factor affecting the content of phosphorus (age, $\mathrm{P}<0.001$ ) and magnesium (age, $\mathrm{P}<0.001$ ) in the blood of rabbits was the age of the animals. According to a posteriori comparisons, significant differences between rabbits of the control and experimental groups were not determined for the content of magnesium and phosphorus in the blood. But we noted the age-related tendency of increasing the content of phosphorus and magnesium in the control and experimental group on the 35th day of the experiment in comparison with the data of these groups on the 21st day of experience. The two factors have a joint and independent effect only in the study of iron content in the blood of rabbits (humic acid additive, $\mathrm{P}<0.001$; age, $\mathrm{P}<0.001$; joint effect, $\mathrm{P}<0.01$ ). We noted an agerelated difference in iron content that was higher by $23.5 \%(\mathrm{P}<0.01)$ in the experimental group on the 14th day relative to the data of the experimental group at the beginning of the experiment.

The content of zinc (humic acid additive, $\mathrm{P}<0.01$ ) in the blood of rabbits was affected only by a biological active feed additive. According to the results of the posterior test, there were no significant differences when comparing the control and experimental groups during the experiment.

The content of copper (humic acid additive, $\mathrm{P}<0.05$; age, $\mathrm{P}<0.001$ ) in the blood was influenced by the humic acid additive and the age of animals. Age-related differences were found in the copper content which 
was significantly higher in the blood of rabbits of the experimental group on the 21st and 35th days of the experiment in comparison with the experimental group on the first and 14th day. We noted the independent effect of age, humic acid additive and joint effect of two factors on the activity of alkaline phosphatase in the blood of rabbits (humic acid additive, $\mathrm{P}<0.01$; age, $\mathrm{P}<0.05$; joint effect, $\mathrm{P}<0.001$ ). The activity of alkaline phosphatase was higher by $26.4 \%(\mathrm{P}<0.05)$ in the experimental group compared with the control on the 35th day of the experiment. A significant increase in alkaline phosphatase activity was observed in rabbits of the experimental group on the 35th day of the experiment compared with the data of the experimental group on the first, 14th and 21st days of the experiment.

A study of bone minerals was carried out after slaughter of rabbits on the 35th day of the experiment. The calcium content in the femur of the experimental group was $23.5 \%$ ( $\mathrm{P}<0.001)$ higher compared with the control (Table 2). We noted an increase in the phosphorus content of the experimental group by $14.0 \%(\mathrm{P}<0.01)$ in comparison with the control. Zinc content was $16.7 \%$ lower $(\mathrm{P}<0.001)$ in animals of the experimental group compared to the control. We observed that the copper content in the experimental group was $15.2 \%$ higher $(\mathrm{P}<0.01)$ compared to the control. The manganese content was $30 \%(\mathrm{P}<0.001)$ higher in the experimental group compared with the control group.

We noted that the calcium content was $13.4 \%$ higher $(\mathrm{P}<0.001)$ in the sternum in the experimental group compared to the control. The zinc content in the experimental group of rabbits was $16.6 \%$ lower $(\mathrm{P}<0.01)$ in comparison to the control. We observed that the copper content was $15.6 \%$ higher $(\mathrm{P}<0.01)$ in the rabbit group compared with the control. To summarize, during the course of the observations, we noted an in- crease in the content of calcium, copper and a decrease zinc in the femur and sternum of the experimental group compared to the control.

\section{Table 2}

The content of minerals in the femur and sternum of rabbits under the impact of humic acid additives $(\mathrm{x} \pm \mathrm{SD}$, $\mathrm{n}=8$, duration of the experiment -35 days)

\begin{tabular}{lcccc}
\hline \multirow{2}{*}{ Indices } & \multicolumn{2}{c}{ Femur bone } & \multicolumn{2}{c}{ Sternum bone } \\
\cline { 2 - 5 } & $\begin{array}{c}\text { control } \\
\text { group }\end{array}$ & $\begin{array}{c}\text { experimental } \\
\text { group }\end{array}$ & $\begin{array}{c}\text { control } \\
\text { group }\end{array}$ & $\begin{array}{c}\text { experimental } \\
\text { group }\end{array}$ \\
\hline $\mathrm{Ca}, \mathrm{g} / \mathrm{kg}$ & $221 \pm 2$ & $273 \pm 15^{* * *}$ & $194 \pm 10$ & $220 \pm 15^{* * *}$ \\
$\mathrm{P}, \mathrm{g} / \mathrm{kg}$ & $41.4 \pm 3.0$ & $47.2 \pm 2.4^{* *}$ & $33.7 \pm 5.7$ & $39.3 \pm 6.7$ \\
$\mathrm{Zn}, \mathrm{mg} / \mathrm{kg}$ & $150 \pm 10$ & $125 \pm 6^{* * *}$ & $64 \pm 5.9$ & $53.4 \pm 3.9^{* *}$ \\
$\mathrm{Cu}, \mathrm{mg} / \mathrm{kg}$ & $3.2 \pm 0.2$ & $3.6 \pm 0.2^{* *}$ & $11.3 \pm 0.7$ & $13.5 \pm 0.8^{* *}$ \\
$\mathrm{Fe}, \mathrm{mg} / \mathrm{kg}$ & $11.1 \pm 1.4$ & $12.9 \pm 1.1$ & $241 \pm 48$ & $292 \pm 36$ \\
$\mathrm{Mn}, \mathrm{mg} / \mathrm{kg}$ & $2.70 \pm 0.32$ & $3.51 \pm 0.41^{* * *}$ & $0.62 \pm 0.22$ & $0.87 \pm 0.21$ \\
\hline
\end{tabular}

Note: $* *-\mathrm{P}<0.01, * * *-\mathrm{P}<0.001$ compared to the control group of animals using one-way ANOVA.

According to the results of a histological examination of the femur, the number of layers of osteons was $16.1 \%$ higher $(\mathrm{P}<0.01)$ in the rabbits of the research group compared with the rabbits of the control group. The number of layers of osteoblasts was $28.1 \%$ more $(\mathrm{P}<0.01)$ in animals in the experimental group compared to the control.

Addition of a humic acid additive increased the number of osteon layers of the femur by $16.1 \%(\mathrm{P}<0.01)$ in rabbits of the experimental group compared to the control(Table 3 ). The number of layers of osteoblasts was higher by $28.1 \%(\mathrm{P}<0.01)$ in animals in the experimental group compared to the control.

Table 3

Histological parameters of the femur and sternum of rabbits under the impact of humic acid additives $(x \pm S D, n=8$, duration of the experiment -35 days)

\begin{tabular}{|c|c|c|c|}
\hline Tissue & Histological parameter & Control group & Experimental group \\
\hline \multirow{5}{*}{$\begin{array}{l}\text { Bone tissue } \\
\text { of the femur }\end{array}$} & The number of layers of outer circumferential lamellae, in the field of view & $2.12 \pm 0.25$ & $2.65 \pm 0.35$ \\
\hline & The number of layers of osteons, in the field of view & $6.00 \pm 0.30$ & $6.84 \pm 0.47 * *$ \\
\hline & The average number of lamellae in osteons, in the field of view & $3.16 \pm 0.30$ & $3.30 \pm 0.45$ \\
\hline & The number of layers of inner circumferential lamellae, in the field of view & $1.31 \pm 0.41$ & $1.55 \pm 0.10$ \\
\hline & Number of osteoblastic layers, in the field of view & $0.64 \pm 0.05$ & $0.82 \pm 0.07 * *$ \\
\hline \multirow{4}{*}{$\begin{array}{l}\text { Bone tissue } \\
\text { of the sternum }\end{array}$} & Number of layers of plates, in the field of view & $11.4 \pm 1.21$ & $13.9 \pm 2.8$ \\
\hline & The number of osteons, in the field of view & $1.73 \pm 0.14$ & $2.06 \pm 0.19 * *$ \\
\hline & The average number of lamellae in osteons, in the field of view & $1.36 \pm 0.17$ & $1.53 \pm 0.25$ \\
\hline & Number of osteoblasts, in the field of view & $3.15 \pm 0.35$ & $3.89 \pm 0.31 * *$ \\
\hline \multirow{2}{*}{$\begin{array}{l}\text { Cartilage tissue } \\
\text { of the chest }\end{array}$} & The number of columns, in the field of view & $58.3 \pm 3.3$ & $67.8 \pm 5.7 * *$ \\
\hline & The number of chondrocytes in the column, in the field of view & $4.01 \pm 0.39$ & $4.99 \pm 0.27 * *$ \\
\hline
\end{tabular}

Note: see Table 2 .

We found an increase in the number of osteons by $19.1 \%(\mathrm{P}<0.01)$ and number of osteoblasts by $23.5 \%(\mathrm{P}<0.01)$ in animals of the experimental group compared to the control. We observed increase in the number of columns of chondrocytes by $16.3 \%(\mathrm{P}<0.01)$ and also an increase in the number of chondrocytes in the column by $24.4 \%(\mathrm{P}<0.01)$ in the experimental group compared to the control.

\section{Discussion}

Humic acid additive and the age of the animals caused independent influence on the calcium content in the blood of rabbits. There was noted dynamics of an increase in calcium content in the experimental group compared with the control. We observed a tendency to increase the calcium content with age in young rabbits of the experimental and control groups. Several possible mechanisms of the effect of humic additive on calcium absorption have been described (Zralý et al., 2010; Trckova et al., 2018). Humic acid additives are known for their chelating properties, which are due to the presence of carboxyl and hydroxyl functional groups in them. Chelating properties affect the bioavailability of macro- and micronutrients for the body (Trckova et al., 2018). In feed, calcium is mainly found in compounds with proteins and lipids. In the gastrointestinal tract, they are affected by hydrochloric acid and enzymes, so they are prepared for absorption. In feed, calcium is mainly found in compounds with proteins and lipids. In the gastrointestinal tract, they are affected by hydrochlor- ic acid and enzymes, releasing calcium for absorption. Humic acid additive can increase the activity of proteolytic and lipolytic enzymes in the gastrointestinal tract (Koljada \& Stepchenko, 2014a, 2014b). The intensification of proteolysis can cause an increase in lysine and arginine. They form soluble complexes with calcium and prevent the formation of insoluble calcium complexes with other components of the feed (Breslau, 1996). An increase in the activity of lipolytic enzymes in the gastrointestinal tract can reduce the number of long chain unsaturated fatty acids, which, together with calcium, form insoluble complexes. The increase in calcium absorption in our experiment can be explained by the chelating properties of humic acid additive. Also, indirect influence on the absorption of calcium can cause an increase in the activity of proteolytic and lipolytic enzymes of the gastrointestinal tract. Increased calcium in the blood of rabbits is due to the features of their calcium metabolism. Rabbits have a more variable concentration of calcium in the blood compared to other mammals. This is due to the need to provide a higher concentration of ionized calcium in the blood to initiate a decrease in parathyroid hormone in comparison with other animal species (Warren et al., 1989). Also, they have a higher importance of passive diffusion in calcium absorption compared to active transport (Kamphues, 1991).

The literature includes statements about ambiguity of the effect of humic additive on the calcium content in the blood. A number of researchers have noted an increase in serum calcium in piglets when humic additive is added to their main diet (Zralý et al., 2010; Trckova et al., 2018). But an 
increase in the blood calcium was not observed in the studies of humic additive in rabbits and birds (Stepchenko et al., 1991; Mista et al., 2012). Yefimov \& Rakytianskyi (2012) noted a decrease in total calcium in the blood of cows when using humic acid additive, which the author associates with the inclusion of calcium in casein milk (Yefimov et al., 2007). The difference in research results is possibly due to the features of mineral metabolism in different animal species. Also in different studies used humates extracted from different sources, which leads to differences in their structure and physiological effects.

In our experiment, the effect of humic acid additive led to an increase in the content of ionized calcium in the blood of the experimental group on the 14th and 21st days of the experiment. This age-related dynamics may be associated with an increase in total serum calcium during this time period. The decrease in the content of ionized calcium on the 35 th day of the study is probably a due of the intensification of bone mineralization.

The content of phosphorus and magnesium in the blood of rabbits was significantly affected only by the age of the animals. The group that received the humic acid additive did not show a great decrease in phosphorus compared to the control.

In the present study, humic acid additive influenced the increase in the iron content in the blood of experimental rabbits during the experiment. A significant increase in iron in the blood was noted on the 14th day of the experiment. This age-related dynamics indicates the primary influence of humic acid additive on iron absorption. It is possible that iron absorption increases due to the intensification of calcium absorption, because it is a non-competitive inhibitor of the DMT-1 transporter, which moves iron to the basolateral surface of the enterocyte (Shawki \& Mackenzie, 2010; Beck et al., 2017). Literature data point out that humic acid additive increases blood iron levels (Ipek et al., 2008; Zralý et al., 2010; Mista et al., 2012). Ipek et al. (2008) note an increased iron content in the blood of Japanese quail. He explains this by increase in its intracellular pool as a result of the chelating properties of humic acid. Szabó et al. (2017) note that the improvement in iron absorption is due to the formation of small complexes of iron with humic acids, which are easily absorbed in the gastrointestinal tract.

We observed that the humic acid additive caused a decrease zinc in the blood of rabbits. The decrease in zinc content is probably a due of its use for the synthesis of alkaline bone phosphatase. Cho et al. (2007) notes the relationship between zinc content and alkaline phosphatase activity in the blood.

The tendency to increased copper content in the blood of rabbits was noted on the 21st day of the experiment. This may be due to a decrease in the antagonistic relationship between copper and zinc during their absorption. Hullár et al. (2018), when giving humic acid additive to rats, notes an improvement in the absorption of copper and zinc. Yefimov \& Rakytianskyi (2012) report a decrease in antagonistic relationships in the exchange of copper and zinc in the cows, which were given hydrohumate with mineral additives.

We found that humic acid additive caused increased activity of alkaline phosphatase. Maybe this is due to the intensification of bone tissue growth and mineralization. The effect of humic acid additive on alkaline phosphatase did not occur quickly; an increase in alkaline phosphatase activity in the experimental group was noted on the 35 th day.

In our experiment, we observed increased calcium levels in the femur and sternum bones of rabbits which received humic acid additive. This may be the result of increased bone growth and an increase in total and ionized calcium in the blood. An increase in alkaline phosphatase activity also indicates an increase in bone growth rate (Pu et al., 2016). The increase in muscle calcium in birds that received humic acid additive was reflected in the literature as early as 1991 (Stepchenko et al., 1991). An increase in the phosphorus content in the femur may be the result of more intensive growth of the femur compared to the sternum bones.

In the present study, humic acid additive increased copper content in the sternum and femur bones. Perhaps this is due to the increase in the inclusion of copper in the composition of lysyloxidase which takes part in the synthesis of collagen (Gromova et al., 2014). We also observed a decreased zinc content in the sternum and femur of rabbits. Probably these changes are due to the inclusion of zinc in the composition of alkaline phosphatase. An increase in the content of manganese in the femur of rabbits is a possible consequence of the increased need for Mn-dependent enzymes. Mn-dependent enzymes are involved in the synthesis of glycosaminoglycans which, together with collagen, form a connective tissue matrix of bone tissue. Gromova et al. (2014) calls copper, zinc and manganese osteotropic minerals, because each of them affects the synthesis of collagen, which composes about $90 \%$ of the bone matrix. Literature data point out that a significant increase was not shown in iron and copper in the bones of rats with the use of humic and fulvic acids, but a decrease in zinc was noted (Szabó et al., 2017; Hullár et al., 2018). Bone tissue remodeling processes in rabbits are faster than other animal species, which may be the reason for the difference between our data and these literature sources (Baofeng et al., 2010).

We observed increase in the number of osteon layers in the bone tissue of the femur and a significant increase in the number of osteons of the sternum. The cartilage tissue of the sternum has an increase in the number of columns of chondrocytes and an increase in the number of chondrocytes in the column. These changes indicate increased growth of bone and cartilage tissue. An increase in the concentration of macronutrients in the sternum and femur, also an increase in the activity of alkaline phosphatase in blood serum, indicates increased growth and mineralization of bone tissue (Cho et al., 2007).

In the literature there is a small amount of information about the effect of humic acid on the histological structure of bone tissue. Çalışır et al. (2015) used systemic administration of humic acids in modeling periodontitis in rats. He noted their anti-inflammatory properties and osteoblastic activity. Durmuş et al. (2017) used an aerosol of humic acids in rat fracture models of the condyle of the lower jaw. He did not observe their positive effect on repair of the condyle of the lower jaw. But he notes that the application of aerosol was single, and recommends further development of dosage forms for the slow withdrawal of humic acid in the fracture zone.

\section{Conclusion}

Addition of humic acid additive to the rabbit diet caused a significant increase in the content of calcium, ionized calcium, iron, copper and a decrease in zinc due to the chelating properties of humic acid. We observed an increase in the content of ionized calcium and iron at the beginning of the experiment and increase in copper content and alkaline phosphatase activity at the end. Also, we note a general tendency toward an increase in the content of macroelements and redistribution of osteotropic trace elements in the femur and sternum bones.

Results of histology examination demonstrate significant increase in the number of osteoblasts in the femur and sternum, which shows intensified growth and mineralization of bone tissue. Humic acid additive caused an increase the number of chondrocyte columns and the number of chondrocytes in the column, which indicates growth of cartilage tissue. Increase in the number of osteon layers of the femur and the number of osteons of the sternum indicates an acceleration of bone growth. To summarize, the use of humic acid additive leads to an intensification of growth and mineralization of bone tissue, which is observed at the molecular and tissue level.

Accelerated growth and increased bone mineralization against the background of the use of humic acid additive opens up prospects for further research on the effect of humic acid additive on reparative osteogenesis and extrapolation of the findings to clinical veterinary medicine.

The authors are grateful to Doctor Vet. Sc., Professor, P. N. Gavrilin for his assistance in the evaluation of morphological parameters.

\section{References}

Baofeng, L., Zhi, Y., Bei, C., Guolin, M., Qingshui, Y., \& Jian, L. (2010). Characterization of a rabbit osteoporosis model induced by ovariectomy and glucocorticoid. Acta Orthopaedica, 81(3), 396-401.

Beck, K. L., \& Coad, J. (2017). Dairy product (Calcium) consumption and iron nutrition. In: Watson, R., Collier, R. J., \& Preedy, V. (Eds.). Nutrients in dairy and their implications on health and disease. Academic Press, Cambridge. Pp. 149-160. 
Beshkenadze, I., Chagelishvili, A., Begheluri, G., Zhorzholiani, N., Gogaladze, M., Urotadze, S., \& Klarjeishvili, N. (2016). New generation premixes for rabbit nutrition. Annals of Agrarian Science, 14(4), 288-291.

Breslau, N. A. (1996). Calcium, magnesium and phosphorus: Intestinal absorption. In: Favus, M. J. (Eds.). Primer on the metabolic bone diseases and disorders of mineral metabolism (2rd ed.). Lippincott-Raven, Philadelphia. Pp. 49-56.

Çalışır, M., Akpınar, A., Poyraz, Ö., Göze, F., \& Çınar, Z. (2015). The histopathological and morphometric investigation of the effects of systemically administered humic acid on alveolar bone loss in ligature-induced periodontitis in rats. Journal of Periodontal Research, 51(4), 499-507.

Cho, Y. E., Lomeda, R. A. R., Ryu, S. H., Sohn, H. Y., Shin, H. I., Beattie, J. H., \& Kwun, I. (2007). Zinc deficiency negatively affects alkaline phosphatase and the concentration of $\mathrm{Ca}, \mathrm{Mg}$ and $\mathrm{P}$ in rats. Nutrition Research and Practice, 1(2), 113-119.

Durmus, K., Bora, A., Dogan, M., Özer, H., Tuncer, E., \& Altuntas, E. (2017). Can local administration of humic acid shorten recovery time of mandibular fractures? Experimental study. Entupdates, 7(2), 57-61.

Garrick, M. D., Singleton, S. T., Vargas, F., Kuo, H. C., Zhao, L., Knöpfel, M., Davidson, T., Costa, M., Paradkar, P., Roth, J., \& Garrick, L. M. (2006). DMT1: Which metals does it transport? Biological Research, 39(1), 79-85.

Gromova, O. A., Torshin, I. J., \& Limanova, O. A. (2014). Kal'cij i ego sinergisty v podderzhke struktury soedinitel'noj i kostnoj tkani [Calcium and its synergists in support connective and bone tissue structures]. Lechashij Vrach, 5, 69-74 (in Russian).

Hullár, I., Vucskits, A. V., Berta, E., Andrásofszky, E., Bersényi, A., \& Szabó, J. (2018). Effect of fulvic and humic acids on copper and zinc homeostasis in rats. Acta Veterinaria Hungarica, 66(1), 40-51.

Ipek, H., Avci, M., Iriadam, M., Kaplan, O., \& Denek, N. (2008). Effects of humic acid on some hematological parameters, total antioxidant capacity and laying performance in Japanese quails. Archiv fur Geflugelkunde, 72, 56-60.

Islam, K. M. S., Schumacher, A., \& Gropp, M. J. (2005). Humic acid substances in animal agriculture. Pakistan Journal of Nutrition, 4(3), 126-134.

Jerney, Z., Bodnar, K., Paraszt, M., Privoczki, Z. I., \& Makra, L. (2017). Global rabbit meat production with a special focus on the role of China. Lucrări Științifice Management Agricultural, 19(3), 31-36.

Kamphues, J. (1991). Calcium metabolism of rabbits as an etiological factor for urolithiasis. Journal of Nutrition, 50, 191-208.

Koliada, S. G., \& Stepchenko, L. M. (2014a). Dynamika zagal'noji lipolitychnoji aktyvnosti u riznyh lokacijah travnogo kanalu strausenjat za diji gumilidu [Dynamics of total lipolytic activity in different locations of the ostrich digestive canal during Humilid action]. Theoretical and Applied Veterinary Medicine, 2(1), 54-60 (in Ukrainian).

Koliada, S. G., \& Stepchenko, L. M. (2014b). Dynamika zagal'noji proteolitychnoji aktyvnosti u riznyh lokacijah travnogo kanalu strausenjat za diji gumili$\mathrm{du}$ [Dynamics of total proteolytic activity in different locations of the ostrich digestive channel during the action of Humilid]. Biologija Tvarin, 16(3), 5359 (in Ukrainian).

Marounek, M., Dušková, D., \& Skřivanová, V. (2003). Hydrolysis of phytic acid and its availability in rabbits. British Journal of Nutrition, 89(3), 287-294.

Mateos, G. G., Rebollar, P. G., \& de Blas, C. (2010). Minerals, vitamins and additives. In: de Blas, C., \& Wiseman, J. (Eds.). Nutrition of the rabbit. CABI Publishing, Oxon. Pp. 119-151.

Mattioli, S., Dal Bosco, A., Duarte, J. M. M., D’Amato, R., Castellini, C., Beone, G. M., Fontanella, M. C., Beghelli, D., Regni, L., Businelli, D., TrabalzaMarinucci, M., \& Proietti, P. (2019). Use of selenium-enriched olive leaves in the feed of growing rabbits: Effect on oxidative status, mineral profile and selenium speciation of Longissimus dorsi meat. Journal of Trace Elements in Medicine and Biology, 51, 98-105.

Miśta, D., Rzasa, A., Wincewicz, E., Zawadzki, W., Dobrzański, Z., Szmańko, T., $\&$ Gelles, A. (2012). The effect of humic-fatty acid preparation on selected haematological and biochemical serum parameters of growing rabbits. Polish Journal of Veterinary Sciences, 15(2), 395-397.
Myhaylenko, E. O., Dyomshyna, O. O., Ushakova, G. O., Griban, V. G., \& Stepchenko, L. M. (2016). Vplyv kormovoji dobavky "Gumilid" na pokaznyky protejinovogo i aminokyslotnogo obminiv u kurchat-brojleriv krosu "Kobb 500" [Influence of feed additive "Humilid" on protein and amino acid metabolism indicators in broiler chickens of cobb 500 cross]. The Animal Biology, 18(4), 66-71 (in Ukrainian).

Pu, F., Chen, N., \& Xue, S. (2016). Calcium intake, calcium homeostasis and health. Food Science and Human Wellness, 5(1), 8-16.

Rybalka, M. A., Stepchenko, L. M., \& Shuleshko, O. O. (2016). Vplyv Gumilidu na pokaznyky bilkovogo obminu ta stan erytrocytopoezu kiz gor'kivs'koji porody [Impact on indicators of Humilid on protein metabolism and the state of the erythropoiesis of Gorky breed goats]. Theoretical and Applied Veterinary Medicine, 4(2), 45-48 (in Ukrainian).

Shawki, A., \& Mackenzie, B. (2010). Interaction of calcium with the human divalent metal-ion transporter-1. Biochemical and Biophysical Research Communications, 393(3), 471-475.

Skorik, M. V. (2008). Vzajemozv'jazok funkcional'nogo stanu erytrocytiv i vmistu mikroelementiv u pechinci kurej-nesuchok za vplyvu guminovyh kormovyh dobavok riznogo pohodzhennja [The interrelation between the functional condition of erythrocytes and the trace element contents in the liver of laying hens in response to huminous feed additives of different origins]. Scientific Bulletin of Lviv National University of Veterinary Medicine and Biotechnology S. Z. Gzhytsky, 10, 190-197 (in Ukrainian).

Stepchenko, L. M., \& Skorik, M. V. (2012). Vpliv gidrogumatu na vmist mineral'nyh elementiv u tkanynah i organah kurchat-brojleriv [Influence of hydrohumat on the content of mineral elements in the tissues and organs of broiler chickens]. Theoretical and Applied Veterinary Medicine, 13(3), 9396 (in Ukrainian).

Stepchenko, L. M., Kryvaya, O. A., \& Chumak, V. O. (2019). Determination of the level of safety of Humilid during biotesting at ciliates. Theoretical and Applied Veterinary Medicine, 7(4), 210-214.

Stepchenko, L. M., Loseva, Y. O., \& Skorik, M. V. (2008). Funkcional'nyj stan organizmu produktyvnoji ptyci za diji gidrogumatu [Functional state of organism of productive poultry exposed to actions of hydrohumat]. News of Dnipropetrovk State Agrarian University, 2, 99-103 (in Ukrainian).

Stepchenko, L. M., Zhorina, L. V., \& Kravtsova, L. V. (1991). The effect of sodium humate on metabolism and resistance in highly productive poultry. Biologicheskie Nauki, 10, 90-95 (in Russian).

Szabó, J., Vucskits, A. V., Berta, E., Andrásofszky, E., Bersényi, A., \& Hullár, I (2017). Effect of fulvic and humic acids on iron and manganese homeostasis in rats. Acta Veterinaria Hungarica, 65, 66-80.

Trckova, M., Lorencova, A., Babak, V., Neca, J., \& Ciganek, M. (2018). The effect of leonardite and lignite on the health of weaned piglets. Research in Veterinary Science, 119, 134-142.

Varga, M. (2014). Text book of rabbit medicine (2nd ed.). Butterworth-Heinemann, Edinburgh. Pp. 123-131.

Vella, D., \& Donnelly, T. M. (2012). Basic anatomy, physiology. In: Carpenter, J. W., \& Quesenberry, K. E. (Eds.). Ferrets, rabbits, and rodents (2rd ed.). Saunders, Philadelphia. Pp. 157-173.

Warren, H. B., Lausen, N. C. C., Segre, G. V., El-Hajj, G., \& Brown, E. M. (1989). Regulation of calciotropic hormones in vivo in the New Zealand white rabbit. Endocrinology, 125(5), 2683-2690.

Yefimov, V. G., \& Rakytianskyi, V. M. (2012). Vplyv guminovyh rechovyn na mineral'nyj obmin u koriv [Effect of humic substances on mineral metabolism in cows]. Theoretical and Applied Veterinary Medicine, 1(1), 66-70 (in Ukrainian).

Yefimov, V. G., Syedykh, N. J., \& Griban, V. G. (2007). Intensivnist' laktopoezu ta sklad moloka koriv za vplyvu gidrogumatu ta solej midi, kobaltu i jodu [Intensity of lactopoiesis and composition of milk of cows under the influence of hydrorubber and salts of copper cobalt and iodine]. Visnyk Sumskoho Natsionalnoho Ahrarnoho Universytetu, 8, 35-37 (in Ukrainian).

Zralý, Z., \& Písaříková, B. (2010). Effect of sodium humate on the content of trace elements in organs of weaned piglets. Acta Veterinaria Brno, 79(1), 73-79. 